Akuntansi dan Manajemen

Vol. 16, No. 2, 2021, Hal. 50-67

\title{
Analisis Standar Belanja (ASB) Pada Pemerintah Kabupaten Padang Pariaman
}

\author{
Dedy Djefris ${ }^{1}$, Eka Rosalina ${ }^{2}$, Rasyidah $^{3}$, Afridian Wirahadi Ahmad ${ }^{4}$, Fauzan \\ Misra5, dan Jane Angrama Eka Putri6 \\ 1,2,4,6Jurusan Akuntansi Politeknik Negeri Padang \\ Email: dedy.djefris@gmail.com \\ Email: ekarosalinapnp5@gmail.com \\ Email: afridianpadang@gmail.com \\ 3 Jurusan Teknologi Informasi Politeknik Negeri Padang \\ Email: rasyidah.faisal@gmail.com \\ 5Jurusan Akuntansi Universitas Andalas \\ Email: maestrolintau@gmail.com \\ *Corresponding author
}

\begin{abstract}
In general, regional financial management goes through the following stages: budget preparation, activity implementation and financial accountability or financial report preparation. Based on the above, Permendagri No. 21 of 2011 concerning Guidelines for Regional Financial Management, states the need for Standard Expenditure Analysis (ASB) as a main research tool in conducting performance-based budgeting. Expenditure Standard Analysis (ASB) is an assessment of the fairness of the costs and workloads used to carry out an activity at each Regional Apparatus Organization (OPD). This study aims to determine the reasonableness of spending in carrying out an activity so as to minimize unclear expenses that cause budget inefficiency. This research was conducted at the Regional Government of Padang Pariaman Regency, West Sumatra. The stages of preparing this Standard Expenditure Analysis (ASB) are to input data and group similar data, determine the Cost Driver, create regression equations, determine the average, upper and lower limits, and analyze the fairness of costs and workloads of the ASB model. has been compiled. The preparation of a Standard Expenditure Analysis (ASB) at the District Government of Padang Pariaman which is discussed in this is for the types of training activities for personnel and training for the community.
\end{abstract}

Keywords: Standard Expenditure Analysis (ASB), regression equation, fairness, and Padang Pariaman Regency 


\begin{abstract}
ABSTRAK
Pengelolaan keuangan daerah secara umum menjalani tahap-tahap yaitu: penyusunan anggaran, pelaksanaan kegiatan dan pertanggungjawaban keuangan atau penyusunan laporan keuangan. Berdasarkan hal di atas Permendagri No. 21 tahun 2011 tentang Pedoman Pengelolaan Keuangan Daerah, menyatakan perlunya Analisis Standar Belanja (ASB) sebagai sarana penelitian pokok dalam melakukan penganggaran berbasis kinerja. Analisis Standar Belanja (ASB) merupakan penilaian kewajaran atas biaya dan beban kerja yang digunakan untuk melaksanakan suatu kegiatan pada setiap Organisasi Perangkat Daerah (OPD). Penelitian ini bertujuan untuk menentukan kewajaran belanja dalam melaksanakan suatu kegiatan sehingga dapat meminimalisir pengeluaran yang tidak jelas yang menyebabkan inefisiensi anggaran. Penelitian ini dilakukan pada Pemerintah Daerah Kabupaten Padang Pariaman Sumatera Barat. Tahapan penyusunan Analisis Standar Belanja (ASB) ini adalah dengan melakukan input data serta pengelompokan data yang sejenis, menentukan Cost Driver, membuat persamaan regresi, menentukan rata-rata, batas atas dan batas bawah, dan menganalisis kewajaran biaya dan beban kerja dari model ASB yang telah disusun. Penyusunan Analisis Standar Belanja (ASB) pada Pemerintah Kabupaten Padang Pariaman yang dibahas dalam adalah untuk jenis kegiatan pelatihan bagi aparatur dan pelatihan bagi masyarakat.
\end{abstract}

Kata kunci: Analisis Standar Belanja (ASB), persamaan regresi, kewajaran, dan Kabupaten Padang Pariaman

\title{
Pendahuluan
}

Didalam otonomi daerah pemerintahan memiliki hak, wewenang dan kewajiban dalam mengatur dan mengurus daerah otonominya sendiri baik dalam urusan pemerintahan dan kepentingan masyarakat setempat sesuai dengan peraturan perundang-undangan yang berlaku. Dengan adanya otonomi daerah akan meningkatkan pelayanan masyarakat itu sendiri dan pemeliharaan hubungan yang harmonis antara pusat dan daerah serta antar daerah yang dikarenakan adanya keadilan nasional. Otonomi daerah memiliki dampak positif terhadap pengelolaan keuangan daerah karena suatu daerah diberi peluang untuk mengelolaan keuangannya sendiri. Hal ini memberikan efesiensi dalam pengelolaan keuangan daerah itu sendiri dimana pemerintah daerah sendiri lah yang memahami kondisi yang ada di daerahnya sendiri.

Menurut Karianga, pengelolaan keuangan daerah secara umum meliputi beberapa tahapan yaitu penyusunan anggaran, tahapan pelaksanaan kegiatan dan tahapan pertanggungjawaban [8]. Tahap penyusunan anggaran memegang peranan penting dalam pengelolaan keuangan daerah. Hal itu dikarenakan pada tahap penyusunan anggaran, pemerintah daerah dapat mencapai tujuan fiskal, meningkatkan koordinasi, membantu efisiensi, keadilan dan transparansi dalam lingkungan serta membantu pemerintah daerah untuk memenuhi kebutuhan prioritas belanja.

Pemberlakuan otonomi daerah di Indonesia juga mengakibatkan perubahan pola pertanggungjawaban daerah atas pengalokasian dana yang dianggarkan oleh daerah (PSKD, 2010). Salah satu perubahan pola pengelolaan keuangan daerah adalah adanya penerapan Anggaran Berbasis Kinerja (ABK). Undang-udang No. 23 Tahun 2014 dimana terakhir diubah dengan undang-undang No. 9 Tahun 2015 tentang pemerintahan daerah yang menegasnya pentingnya Anggaran Berbasis Kinerja (ABK). Anggaran berbasis 


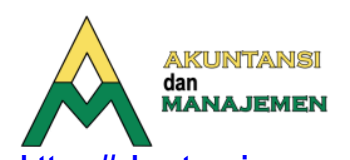

https://akuntansi.pnp.ac.id/jam

kinerja (ABK) adalah suatu ketetapan dalam melaksanakan satu atau lebih kegiatan oleh instansi daereh untuk mencapai tujuannya. ABK ini digunakan untuk memperoleh alokasi anggaran atau yang dikoordinasikan oleh instansi pemerintah sehingga biaya yang anggaran dalam Renja-SKPD disetiap unit-unit kinerja pada suatu instansi pemerintah dapat dipertanggung jawabkan kemanfaatan anggarannya kepada DPR dan masyarakat luas.

Dalam tahap penyusunan anggaran kegiatan-kegiatan dan hal-hal yang dianggarkan akan dicantumkan dalam suatu Dokumen Pelaksanaan Anggaran (DPA). Jika dalam satu semester terjadi perubahan-perubahan yang tidak terduga Organisasi Perangkat Daerah (OPD) akan mengajukan perubahan tersebut dalam Dokumen Perubahan Pelaksanaan Anggaran (DPPA). DPA/DPPA menjadi pertanggungjawaban atas kegiatan yang dilaksanakan oleh (OPD) atau Satuan Kerja Perangkat Daerah (SKPD). Dari DPA/DPPA itu nantinya akan disusun Analisis Standar Belanja (ASB). Analisis Standar Belanja (ASB) merupakan suatu standar yang digunakan untuk menentukan anggaran belanja daerah yang digunakan dalam suatu program atau kegiatan untuk menghasilkan tingkat pelayanan tertentu dan kewajaran biaya di unit kerja dalam satu tahun anggaran. ASB dipertegas dengan terbitnya PP No. 12 Tahun 2019 tentang Pengelolaan Keuangan Daerah yang ditempatkan dalam Lembaran Negara Republik Indonesia Tahun 2019 Nomor 42 serta penjelasan Atas PP 12 tahun 2019 tentang Pengelolaan Keuangan Daerah.

Analisis standar belanja (ASB) merupakan suatu instrumen penyusunan anggaran berbasis kinerja dimana telah diatur dalam peraturan pemerintah Nomor 105 Tahun 2000 tentang Pengelolaan dan Pertanggungjawaban Keuangan Daerah. Namun istilah yang digunakan dalam Peraturan Pemerintah tersebut masih Standar Analisis Belanja (SAB). SAB memiliki makna dan tujuan yang sama dengan ASB yaitu suatu instrumen untuk menilai penilaian kewajaran atas beban kerja dan biaya yang digunakan untuk melaksanakan suatu kegiatan. ASB dapat menentukan kewajaran biaya dan beban kerja untuk melaksanakan kegiatan sehingga hal itu dapat meminimalisir terjadinya pengeluaran yang kurang jelas yang menyebabkan inefesiensi anggaran.

Kewajaran biaya adalah biaya per komponen atau biaya total yang wajar untuk menyelesaikan suatu kegiatan tertentu atau untuk menghasilkan satuan output tertentu. Dalam melakukan penilaian kewajaran biaya hal-hal yang harus dilakukan adalah menghitung rata-rata, batas bawah dan batas atas sesuatu kegiatan ASB yang disusun berdasarkan persamaan yang telah disusun. Beban kerja adalah komponen belanja yang mencerminkan tahapan pelaksanaan kegiatan, terdiri dari: belanja pegawai, belanja barang/jasa, dan belanja modal yang dapat menyelesaikan suatu kegiatan tertentu atau untuk menghasilkan satuan output tertentu.

Terkait dengan peraturan diatas, maka seluruh daerah berkewajiban menyusun Analisis Standar Belanja (ASB) dalam menilai kewajaran suatu anggaran tanpa terkecuali Pemerintah Kabupaten Padang Pariaman. Dalam kasus ini Pemerintahan Kabupaten Padang Pariaman belum memiliki Analisis Standar Belanja (ASB) Sendiri. 


\section{Landasan Teori}

\section{Otonomi Daerah}

Indonesia menganut sistem otonomi daerah dalam pelaksanaan pemerintahannya. Sistem otonomi daerah memungkinkan pemerintah daerah mempunyai hak dan kewajiban untuk mengatur daerahnya sendiri. Tetapi, dalam melaksanakan otonominya daerah masih tetap akan dikontrol oleh pemerintah pusat serta sesuai dengan undangundang. Miriam Budiardjo menjelaskan pemerintah pusat mempunyai wewenang menyerahkan sebagian kekuasaannya ke daerah berdasarkan hak otonomi. Penyerahan sebagian kekuasaan itu dilakukan karena Indonesia adalah negara kesatuan dengan sistem desentralisasi [4]. Namun, hal itu tidak mempungkiri peranan dari pemerintah pusat karena pada tahap terakhir kekuasaan tertinggi tetap di tangan pemerintah pusat. Otonomi daerah memiliki beberapa dasar hukum yang menjelaskan peraturan terkait otonomi itu sendiri.

\section{Pengelolaan Keuangan Daerah}

Pengelolaan Keuangan Daerah diatur oleh Undang-Undang Nomor 23 tahun 2014 tentang Pemerintahan Daerah. Ketentuan Undang-Undang Nomor 23 Tahun 2014 Pasal 293 dan Pasal 330 tentang Pemerintahan Daerah memberikan amanat untuk mengatur Pengelolaan Keuangan Daerah dengan sebuah Peraturan Pemerintah. Pengelolaan Keuangan Dareah juga diatur dalam Peraturan Pemerintah Republik Indonesia Nomor 12 tahun 2019. Peraturan Pemerintah ini ditetapkan oleh Presiden Joko Widodo pada tanggal 6 Maret 2019 di Jakarta. PP 12 tahun 2019 diundangkan dan ditempatkan dalam Lembaran Negara Republik Indonesia Tahun 2019 Nomor 42. Penjelasan Atas PP 12 tahun 2019 dalam Tambahan Lembaran Negara Republik Indonesia Nomor 6322, oleh Menkumham Yasonna H. Laoly pada tanggal 12 Maret 2019 di Jakarta.

Pengelolaan Keuangan Daerah [1] adalah keseluruhan kegiatan yang meliputi perencanaan, penganggaran, pelaksanaan, penatausahaan, pelaporan, pengawasan, dan pertanggungjawaban Keuangan Daerah. Keuangan Daerah adalah semua hak dan kewajiban Daerah dalam rangka penyelenggaraan Pemerintahan Daerah yang dapat dinilai dengan uang serta segala bentuk kekayaan yang dapat dijadikan milik Daerah berhubung dengan hak dan kewajiban Daerah tersebut. Keuangan Daerah selain diatur dengan Peraturan Pemerintah juga mengikuti Peraturan Menteri dan keuangan daerah juga mengikuti Undang-Undang Anggaran Pendapatan dan Belanja Negara yang ditetapkan setiap tahun, dan Anggaran Pendapatan dan Belanja Daerah masing-masing daerah yang disinkronkan dan dikelola secara sistematis.

\section{Anggaran Berbasis Kinerja (ABK)}

Prinsip anggaran berbasis kinerja secara teori adalah anggaran yang menghubungkan anggaran negara (pengeluaran negara) dengan hasil yang diinginkan (output dan outcome) sehingga setiap rupiah yang dikeluarkan dapat dipertanggungjawabkan kemanfaatannya [2]. Abdul Halim mendefinisikan anggaran berbasis kinerja sebagai metode penganggaran bagi manajemen untuk mengaitkan setiap pendanaan yang 
dituangkan dalam kegiatan-kegiatan dengan keluaran dan hasil yang diharapkan termasuk efisiensi dalam pencapain hasil dari keluaran tersebut [6]. Keluaran dan hasil tersebut dituangkan dalam target kinerja pada setiap unit kinerja.

Anggaran berbasis kinerja (Performance Based Budgeting) merupakan sistem penganggaran yang berorientasi pada output organisasi dan berkaitan sangat erat dengan visi, misi, dan rencana strategis organisasi. Anggaran yang tidak efektif dan tidak berorientasi pada kinerja akan dapat menggagalkan perencanaan yang telah disusun. Pengukuran kinerja secara berkelanjutan akan memberikan umpan balik, sehingga upaya perbaikan secara terus menerus akan mencapai keberhasilan di masa mendatang [1].

Menurut Undang-Undang No. 17 Tahun 2003, pengertian anggaran berbasis kinerja adalah suatu pendekatan dalam penyusunan anggaran yang didasarkan pada kinerja atau prestasi kerja yang ingin dicapai. Mardiasmo (2002) menyatakan bahwa pendekatan penyusunan anggaran berbasis kinerja disusun untuk mengatasi berbagai kelemahan yang terdapat dalam anggaran tradisional, khususnya kelemahan yang disebabkan oleh tidak adanya tolak ukur yang dapat digunakan untuk mengukur kinerja dalam pencapaian tujuan dan sasaran pelayanan publik. Anggaran dengan pendekatan kinerja sangat menekankan konsep value for money dan pengawasan atas kinerja output.

\section{Konsep Analisis Standar Belanja (ASB)}

Analisa Belanja Umum menjelaskan bahwa Analisis standar Belanja (ASB) merupakan penilaian kewajaran atas beban kerja dan biaya yang digunakan untuk melaksanakan kegiatan Organisasi Perangkat Daerah (OPD) dilingkungan Pemerintah Provinsi Sumatera Barat. Terdapat dua hal penting dalam pengertian tersebut yakni kewajaran atas beban kerja dan kewajaran biaya. Kewajaran yang dimaksud adalah kewajaran penganggaran atas suatu kegiatan, sehingga orientasi standar ini ditujukan pada kegiatan yang diusulkan.

Menurut Tim ASB Universitas Andalas [13], penyusunan ASB seharusnya dilakukan pada awal setiap proses penyusunan anggaran. Hal ini karena ASB dibutuhkan oleh OPD sebagai pedoman dalam mengajukan jumlah anggaran belanja untuk suatu kegiatan yang terangkum dalam Rencana Kerja dan Anggaran (RKA) OPD. Dengan berpedoman kepada ASB, OPD dapat menyusun anggaran sesuai dengan prinsip-prinsip penganggaran yang baik yang salah satunya dengan memperhatikan faktor kewajarannya. Di sisi sebaliknya, TAPD dengan berpedoman kepada ASB dapat dengan baik pula mengevaluasi kewajaran atas anggaran yang diusulkan oleh masing-masing OPD.

\section{Dasar Hukum ASB}

Adapun dasar hukum dalam menerapkan ASB dalam penyusunan anggaran belanja kegiatan pada setiap pemerintahan daerah adalah:

1. UU nomor 17 tahun 2003 tentang keuangan negara menetapkan bahwa APBD disusun berdasarkan pendekatan prestasi kerja. Untuk itu APBD berbasis kinerja 
disusun oleh Pemda harus didasarkan pada Standar Pelayanan Minimum (SPM) dan Analisis Standar Belanja (ASB).

2. Undang-Undang Nomor 1 Tahun 2004 tentang Perbendaharaan Negara.

3. Undang-Undang Nomor 15 Tahun 2004 tentang Pemeriksaan Pengelolaan dan TanggungJawab Keuangan Negara.

4. Undang-Undang Nomor 33 Tahun 2004 tentang Perimbangan Keuangan Antara Pemerintah Pusat dan Pemerintah Daerah.

5. Undang-Undang Nomor 23 tahun 2014 tentang Pemerintahan Daerah. Dalam UU No. 23 Tahun 2014 Pasal 298 ayat (3), " belanja daerah untuk pendanaan urusan pemerintah yang jadi kewenangan daerah selain sebagaimana yang dimaksud pada ayat 1 berpedoman pada analisis standar belanja dan standar harga satuan regional sesuai dengan ketentuan peraturan perundang-undangan."

6. Peraturan Pemerintah Nomor 105 Tahun 2000 tentang Pengelolaan dan Pertanggungjawaban Keuangan Daerah pasal 20 ayat (2) "Untuk mengukur kinerja pemerintah daerah, dikembangkan analisa standar belanja, tolak ukur kinerja dan standar biaya."

7. PP 12 tahun 2019 tentang Pengelolaan Keuangan Daerah diundangkan dan ditempatkan dalam Lembaran Negara Republik Indonesia Tahun 2019 Nomor 42 dan Penjelasan Atas PP 12 tahun 2019 tentang Pengelolaan Keuangan Daerah ditempatkan dalam Tambahan Lembaran Negara Republik Indonesia Nomor 6322.

8. Peraturan Menteri Dalam Negeri Nomor 13 Tahun 2006 tentang Pedoman Pengelolaan Keuangan Daerah pasal 89 ayat 2 huruf e, pasal 93 ayat 1, dan pasal 100 ayat 2 .

9. Permendagri Nomor 21 tahun 2011 tentang Perubahan Kedua atas Permendagri Nomor 13 tahun 2006 tentang Pedoman Pengelolaan Keuangan Daerah. ASB merupakan salah satu instrumen pokok dalam penganggaran berbasis kinerja.

10. PERBUP Nomor 652/ Kep/BPP/2017 Tentang Penetapan Standar Satuan Harga Barang dan Jasa Kebutuhan Pemerintah Kabupaten Padang Pariaman Tahun Anggaran 2018.

11. Peraturan Bupati Padang Pariaman Nomor 31 Tahun 2017 Tentang Analisis Standar Belanja (ASB).

\section{Tujuan ASB}

Tujuan Analisis Standar Belanja [11] sebagai berikut:

1. Meningkatkan kemampuan unit kerja dalam menyusun anggaran berdasarkan skala prioritas APBD, tugas pokok dan fungsi, tujuan, sasaran, serta indikator kinerja pada setiap program dan kegiatan yang direncanakan.

2. Mencegah terjadinya duplikasi dan atau tumpang tindih kegiatan dan anggaran belanja pada masing-masing dan antar unit kerja. 
3. Menjamin kesesuaian antara kegiatan dan anggaran dengan arah, kebijakan umum dan prioritas penyelenggaraan pemerintah dan pelayanan publik, mengurangi tumpang tindih belanja dalam kegiatan investasi dan non investasi.

4. Meningkatkan efisiensi, efektivitas, dan akuntabilitas anggaran belanja dalam perencanaan, pelaksanaan, dan pengendalian.

\section{Manfaat ASB}

Dalam modul analisis standar belanja PSKD [11] penyusunan ASB dapat bermanfaat untuk:

1. Pemerintah Daerah dapat menentukan kewajaran belanja dalam pelaksanaan suatu kegiatan sesuai dengan tugas pokok dan fungsinya.

2. Pemerintah Daerah dapat meminimalisir terjadinya pengeluaran yang kurang jelas yang menyebabkan inefisiensi anggaran.

3. Menghindari tumpang tindih program dan anggaran antar unit kerja.

4. Penentuan anggaran berdasarkan pada tolak ukur kinerja yang jelas.

5. Unit kerja mendapat keleluasaan yang lebih besar untuk menentukan anggarannya sendiri dengan tidak melanggar prinsip value for money.

Di samping itu, manfaat yang dapat diperoleh dari pemerintah daerah ketika menggunakan ASB diantaranya [9]:

1. Penetapan plafon anggaran pada saat Prioritas dan Plafon Anggaran Sementara (PPAS) menjadi objektif tidak lagi berdasarkan "intuisi";

2. Dapat menentukan kewajaran biaya untuk melaksanakan suatu kegiatan;

3. Meminimalisir terjadinya pengeluaran yang kurang jelas yang menyebabkan inefisiensi anggaran;

4. Penentuan anggaran berdasarkan tolok ukur kinerja yang jelas;

5. Penentuan besaran alokasi setiap kegiatan menjadi objektif;

6. Penyusunan anggaran menjadi lebih tepat waktu.

\section{Peranan ASB dalam Penyusunan APBD}

Peraturan Menteri Dalam Negeri Nomor 13 tahun 2006 pasal 93 ayat 1 menyatakan bahwa penyusunan RKA-OPD berdasarkan pada ASB (salah satu dasar), dan pada ayat 4 menyatakan bahwa ASB merupakan penilaian kewajaran atas beban kerja dan biaya yang digunakan untuk melaksanakan suatu kegiatan, serta memperhatikan prinsipprinsip dasar penyusunan ASB. Maka dapat dikatakan peranan ASB dalam penyusunan anggaran pada pemerintah daerah adalah sebagai berikut:

1. Menjamin kewajaran beban kerja dan biaya yang digunakan antar OPD dalam melakukan kegiatan sejenis.

2. Mendorong terciptanya anggaran daerah yang semakin efisien dan efektif.

3. Memudahkan TAPD melakukan evaluasi terhadap total belanja yang diajukan dalam RKA-OPD untuk setiap kegiatan. 
4. Memudahkan OPD dan TAPD dalam menghitung besarnya anggaran total belanja untuk setiap jenis kegiatan berdasarkan target output yang ditetapkan dalam RKA-OPD.

\section{Prinsip Penyusunan ASB}

Menurut Tim ASB Universitas Andalas [13], ada beberapa prinsip dasar yang harus diperhatikan pemerintah daerah yaitu:

1. Penyederhanaan (Modeling)

Penyusunan ASB bertujuan membuat model belanja untuk objek-objek kegiatan yang menghasilkan output yang sama.

2. Mudah diaplikasikan

Model yang dibuat mudah diaplikasikan atau tidak membuat susah yang menggunakan model tersebut.

3. Mudah diup-date

Model yang dibuat mudah untuk diperbaruhi dalam arti jika ditambahkan datadata baru tidak merubah formula model tersebut secara keseluruhan.

4. Fleksibel

Dalam hal ini model yang dibuat menggunakan konsep belanja rata-rata dan memiliki batas minimum belanja dan batas maksimum belanja.

\section{Metode Penelitian}

Menurut modul analisis standar belanja PSKD [11] untuk menghasilkan ASB yang layak dan dapat diterapkan oleh Pemerintah Kota Padang maka dilakukan beberapa tahapan kegiatan sebagai berikut:

\section{Tahap Pengumpulan Data}

Tahap pengumpulan data merupakan tahap pengambilan data berupa Dokumen Pelaksanaan Anggaran (DPA) untuk tahun 2020 dan Dokumen Perubahan Pelaksanaan Anggaran (DPPA) untuk tahun 2019 dan 2018 ke setiap OPD pada daerah yang ditentukan dan juga mendapatkan data-data yang diperlukan melalui wawancara kepada pihak terkait.

Y dan X merupakan nilai-nilai yang diperoleh dari pengamatan data yang ada, dengan demikian yang perlu ditaksir adalah koefisien A dan B. Penggunaan regresi sederhana dalam menyusun ASB berguna untuk membuat model (persamaan) regresi untuk peramalan belanja dari suatu kegiatan. Peramalan belanja dengan model regresi ini dengan cara menghitung belanja rata-rata, menghitung batas minimum belanja, dan batas maksimum belanja, serta menghitung persentase alokasi kepada masing-masing objek belanja. Dalam menentukan nilai persamaan regresi ini dibantu dengan menggunakan program SPSS. 


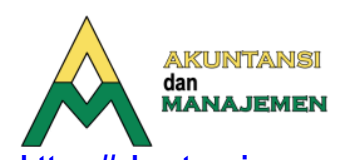

https://akuntansi.pnp.ac.id/jam

e-ISSN 2657-1080, p-ISSN 1858-3687

\section{Tahap Inventarisasi Data}

Inventarisasi data merupakan kegiatan menginput data seluruh kegiatan belanja langsung dari DPA ke dalam file microsoft excel. Hal ini bertujuan untuk mendapatkan informasi tentang kegiatan-kegiatan yang berulang dalam suatu OPD atau kegiatan yang terjadi pada beberapa OPD. Inventarisasi data ini juga bermanfaat untuk memudahkan pengolahan data kegiatan untuk tahap berikutnya. Data anggaran di Dokumen Pelaksanaan Anggaran (DPA) diinputkan dalam kolom tersendiri berdasarkan alokasi belanja masing-masing jenis kegiatan.

\section{Menentukan Cost Driver}

Cost driver merupakan faktor pemicu besarnya jumlah biaya yang terjadi dalam suatu aktivitas. Misalnya besarnya biaya pelatihan akan dipicu (merupakan cost driver) oleh jumlah peserta serta lamanya pelatihan. Cost driver berbeda-beda antara satu ASB dengan ASB lainnya tergantung pada jenis kegiatan yang dilaksanakan. Untuk menentukan cost driver dapat dilakukan dengan membandingkan pemicu biaya yang mengakibatkan suatu biaya berubah pada kegiatan yang sama dari data 3 tahun.

\section{Melakukan Pengujian Menggunakan Diagram Scatter Plot}

Menurut Gunawan, diagram pencar atau diagram serak (scatter plot) merupakan alat berupa diagram yang digunakan untuk menunjukkan ada tidaknya hubungan antara variabel X dan variabel Y melalui penggambaran nilai dari variabel-variabel tersebut [5]. Diagram pencar menggunakan sistem koordinat cartesius. Pada koordinat tersebut, pada sumbu X diletakkan nilai variabel bebas dan pada sumbu Y diletakkan nilai variabel terikat (Y). Tujuan diagram pencar untuk mengetahui apakah titik-titik koordinat diagram membentuk pola tertentu.

Dalam diagram selanjutnya ditarik suatu garis yang dapat membagi dua titik koordinat pada kedua sisinya. Garis yang ditarik diupayakan sesuai menggambarkan kecenderungan data yang tersebar (garis best fit). Dari garis tersebut dapat diketahui korelasi antara dua variabel sekaligus arah atau bentuk hubungan. Jika garis naik artinya hubungan positif dan jika arah garis turun maka jenis hubungan negatif.

Selain itu jika antara dua varibael bebas dan variabel terikat membentuk atau mendekati garis lurus, maka data tersebut bersifat linear. Sebaliknya jika data antara variabel bebas dan variabel terikat tidak membentuk atau mendekati garis lurus, maka data tersebut tidak bersifat linear. Dapat disimpulkan dalam melakukan pengujian menggunakan diagram scatter plot ini syarat-syaratnya adalah adanya hubungan positif antar dua variabel dan data bersifat linear.

\section{Penyusunan Model ASB Untuk Masing-Masing Kegiatan}

Pada tahap penyusunan model analisis standar belanja untuk masing-masing kegiatan ini dapat dilakukan dengan beberapa langkah sebagai berikut: 


\section{a. Menentukan persentase rata-rata, batas atas, dan batas bawah}

Setelah tahap persamaan regresi yang didapat untuk mencari total anggaran yang dibuat berdasarkan cost driver masing-masing. Tahap berikutnya adalah menentukan persentase yang akan menjadi acuan tim penyusunan anggaran dalam menentukan nilai rincian alokasi belanja kegiatan tersebut. Setiap rincian alokasi belanja akan diberikan acuan rata-rata, batas atas dan batas bawah yang akan diolah dari data yang ada. Untuk menentukan nilai persentase rata-rata, batas atas dan batas bawah tersebut digunakan persamaan sebagai berikut [11]

\section{b. Menentukan persamaan regresi dari setiap ASB}

Menurut Blocher, dkk[3], analisis regresi (regression anlysis) merupakan metode statistik untuk memperoleh persamaan estimasi biaya unik yang paling sesuai bagi sekumpulan titik data. Adapun persamaan regresi, yaitu:

Persamaan 2.2.

$$
Y=A+B(X)
$$

Keterangan:

$\mathrm{Y}=$ Total Anggaran Belanja

$X=$ Pemicu Biaya (cost driver)

$\mathrm{A}=$ Biaya Tetap (fixed cost)

$\mathrm{B}=$ Biaya Variabel (variabel cost)

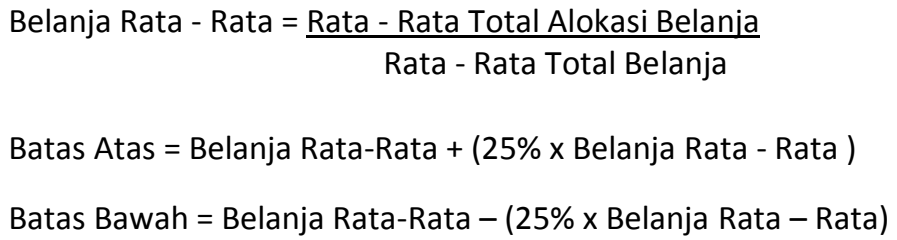

Sumber: PSKD [11]

Penetapan $25 \%$ atau 0,25 dari nilai rata-rata didasarkan atas kesepakatan dengan OPD terkait melalui Focus Group Discussion (FGD). 


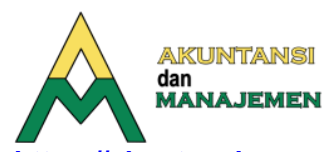

https://akuntansi.pnp.ac.id/jam

e-ISSN 2657-1080, p-ISSN 1858-3687

\section{Hasil Penelitian \& Pembahasan}

\section{Uraian Masalah}

Dalam rangka penyusunan rancangan anggaran pendapatan dan belanja daerah (RAPBD) tahun 2021 terdapat kegiatan dan pendapatan yang disusun oleh pemerintah Kabupaten Padang Pariaman. Terkait pendanaan suatu kegiatan tersebut pemerintah harus menyusun pedoman anggaran agar anggaran yang ditetapkan sesuai dengan kinerja yang diinginkan. Berdasarkan hal tersebut ASB sangat dibutuhkan dalam kegiatan pemerintah untuk menentukan kewajaran nilai biaya dan beban suatu kegiatan dalam tahap perencanaan/penganggaran maupun evaluasi.

ASB merupakan amanah dari Undang-Undang. ASB dipertegas dengan terbitnya PP No. 12 Tahun 2019 tentang Pengelolaan Keuangan Daerah diundangkan dan ditempatkan dalam Lembaran Negara Republik Indonesia Tahun 2019 Nomor 42 dan Penjelasan Atas PP 12 tahun 2019 tentang Pengelolaan Keuangan Daerah ditempatkan dalam Tambahan Lembaran Negara Republik Indonesia Nomor 6322. Analisis Standar Belanja (ASB) sebagai salah satu instrumen anggaran berbasis kinerja sebagaimana diatur dalam peraturan pemerintah Nomor 105 Tahun 2000 tentang Pengelolaan dan Pertanggungjawaban Keuangan Daerah.

Pemerintah Kabupaten Padang Pariaman belum memiliki acuan khusus yang diterapkan secara optimal dalam penganggaran kegiatan-kegiatan yang sering dilaksanakan dan spesifik oleh OPD di lingkungan Pemerintah Kabupaten Padang Pariaman. Hal itu menyebabkan penilaian kewajaran atas beban kerja dan biaya kegiatan pada OPD Pemerintah Kabupaten Padang Pariaman masih bervariasi. Untuk mengatasi masalah ini, Pemerintah Kabupaten Padang Pariaman perlu menyiapkan alat-alat penunjang Teknis Pengelolaan Keuangan Daerah untuk kegiatan-kegiatan sejenis yang ada pada OPD. Berdasarkan permasalahan di atas, Pemerintah Kabupaten Padang Pariaman sudah seharusnya mengembangkan dan menyusun ASB sebagai panduan formal antara input yang dikonsumsi dengan output yang diinginkan. Dengan demikian nantinya dapat digunakan sebagai alat ukur untuk menilai kewajaran biaya untuk biaya kegiatan dan beban kerja pada setiap OPD di Kabupaten Padang Pariaman.

\section{Pembahasan}

Sebagaimana yang telah dijelaskan dalam bab satu mengenai batasan masalah, kegiatan yang akan dibahas dalam tugas akhir ini hanya dua kegiatan saja. Kegiatan tersebut adalah Pelatihan Bagi Aparatur dan Sosialisasi Bagi Masyarakat. Berikut adalah rancangan ASB pada pemerintah kabupaten padang pariaman.

\section{Analisis Standar Belanja (ASB) Kegiatan Pelatihan Bagi Aparatur}

Pelatihan Bagi Aparatur/pegawai merupakan kegiatan untuk memberikan kepada para aparatur sipil negara di lingkungan Pemerintah Kabupaten Padang Pariaman yang dilaksanakan sendiri oleh Organisasi Perangkat Daerah (OPD) Pemerintah Kabupaten Padang Pariaman dan dilaksanakan di aula pertemuan atau tempat lainnya seperti di 


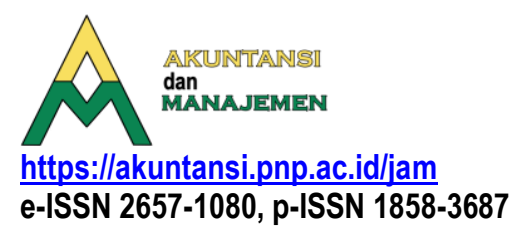

Hotel (Penelitian ASB Padang Pariaman,2020). Pelatihan Bagi Aparatur/pegawai memberikan pelatihan kepada para pegawai dilingkungan OPD padang pariaman untuk memperoleh keahlian tertentu. Tujuan kegiatan ini adalah memberikan keahlian teknis, tata cara dalam mengatasi masalah kegiatan operasional dan mengingkatkan kemampuan sumber daya manusia pada aparatur daerah Padang Pariaman.

Berikut adalah langkah-langkah dalam menyusun analisis standar belanja (ASB) Pelatihan Bagi Aparatur:

\section{Tahap pengumpulan data kegiatan pelatihan bagi aparatur}

Pada tahap ini mengumpulkan data terkait kegiatan pelatihan yang dilaksanakan oleh aparatur dalam bentuk Dokumen Pelaksanaan Anggaran (DPA) atau Dokumen Perubahan Pelaksanaan Anggaran (DPPA) selama tiga tahun terakhir yaitu tahun 2018, 2019 dan 2020 pada pemerintah daerah padang pariaman.

\section{Inventarisasi data kegiatan pelatihan bagi aparatur}

Berdasarkan data yang dikumpulkan tersebut selanjutnya melakukan pengelompokan data dalam bentuk tabel pada Microsoft Excel. Hal ini bertujuan untuk mendapatkan kegiatan-kegiatan yang berulang pada suatu OPD atau kegiatan yang terjadi dari beberapa OPD. Berdasarkan penjelasan anggaran berbasis kinerja ASB yang disusun adalah berdasarkan kegiatan yang melakukan belanja langsung saja. Data yang dikumpulkan tersebut berisikan tahun pelaksanaan, nama OPD yang melaksanakan kegiatan, nama kegiatan, total belanja dalam melaksanakan kegitan tersebut dan rincian/alokasi dari total belanja. Setelah dikumpulkan terdapat 16 data yang layak diolah pada ASB Pelatihan Bagi Aparatur.

Dari data yang yang telah diimput ke dalam Microsoft Excel kemudian dilakukan penyetaraan data. Penyetaraan kegiatan dilakukan untuk mengelompokkan berbagai kegiatan dari tahap pengumpulan data ke dalam jenis atau kategori kegiatan yang memiliki pola dan kemiripin yang sama dengan nilai belanja yang sepadan.

\section{Menentukan cost driver kegiatan pelatihan bagi aparatur}

Berdasarkan pengamatan data yang dikumpulkan beserta diskusi, maka ditetapkan cost driver untuk ASB pelatihan yang dilaksanakan aparatur adalah:

Jumlah Peserta Pelatihan x Jumlah Jam Pelatihan

Cost driver menjelaskan bahwa semakin banyak jumlah peserta pelatihan dan jumlah jam pelatihan maka semakin besar juga beban belanja yang akan dikeluarkan dalam melaksanakan kegiatan ASB Pelatihan Bagi Aparatur, begitu juga sebaliknya. Setalah menentukan cost driver pada ASB Pelatihan Bagi Aparatur selanjutnya adalah 
menghitung berapa cost driver di setiap kegiatan. Untuk menganalisis dan mendapatkan nilai cost driver yang tepat.

\section{Melakukan pengujian dengan menggunakan diagram pencar /scatter plot kegiatan pelatihan bagi aparatur}

Langkah selanjutnya adalah menyeleksi data yang tepat untuk dimasukkan kedalam model ASB pelatiahan bagi aparatur. Dalam melakukan kegiatan ini kita dapat menggunakan diagram pencar/scatter plot untuk melakukan pengujian data.

Setelah dilakukan pengujian dengan menggunakan diagram pencar/scatter plot, maka terbentuklah hubungan antara variabel $\mathrm{x}$ (cost driver) dan variabel $\mathrm{y}$ (total belanja). Namun jika terlihat dari diagram tersebut terdapat sebaran data yang maka data tersebut tidak layak yang dapat merusak model ASB yang diinginkan. Data yang tidak layak akan dihapuskan dalam menganalisis ASB Pelatihan Bagi Aparatur. Selanjutnya setalah tertinggal data yang layak maka dilakukan sekali lagi pengujian dengan menggunakan diagram pencar/scatter plot. Dapat dilihat pada gambar dibawah ini:

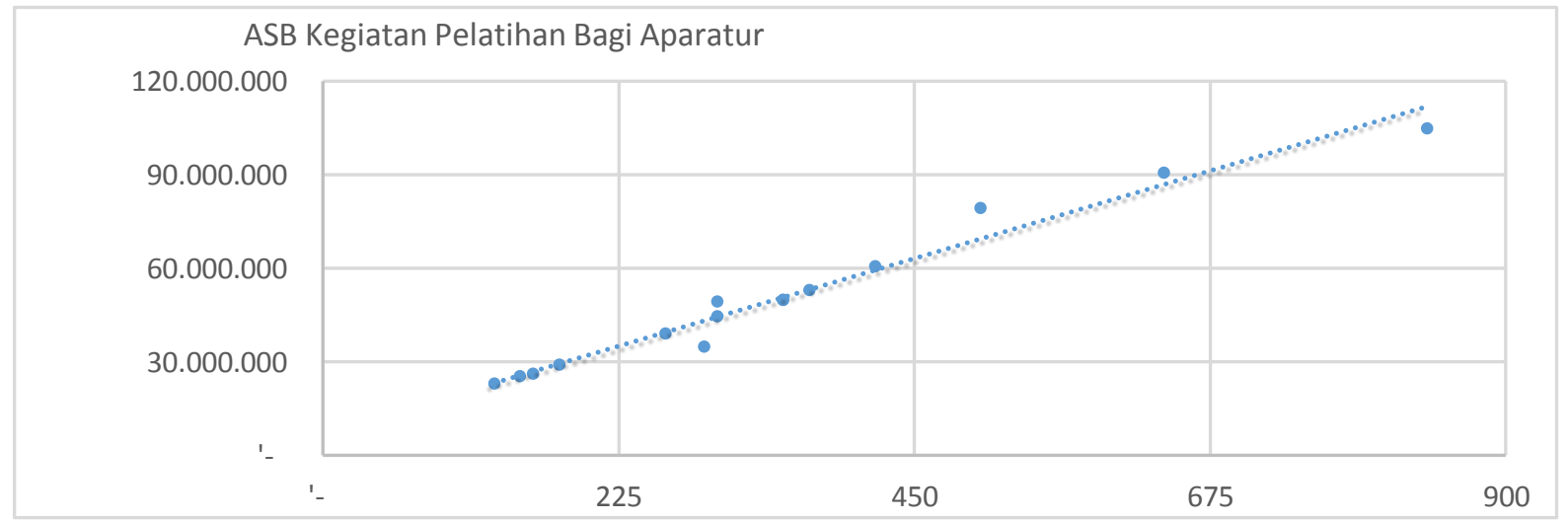

Gambar 1. Diagram Pencar/Scatter Plot ASB Pelatihan Bagi Aparatur

Dari gambar diatas sudah terlihat bahwa gambar sudah tersebar dengan baik dan tidak ada data terpencil atau tidak layak, sehingga data tersebut layak untuk dimasukkan membuat model/persamaan regresi.

\section{Penyusunan model ASB kegiatan pelatihan bagi aparatur}

Langkah-langkah dalam menyusun ASB Pelatihan Bagi Aparatur yaitu:

a. Membuat persamaan regresi

Analisis regresi adalah salah satu metode yang menentukan hubungan sebab akibat antara satu variabel dengan variabel lainnya. Variabel "penyebab" sering kali digambarkan dalam grafik sebagai sumbu $\mathrm{x}$ dan variabel terkena akibat digambarkan dengan sumbu y. variabel bebas itu adalah sumbu x dan variabel tidak bebas adalah sumbu y. dalam regresi ini variabel bebas adalah cost driver sedangkan 


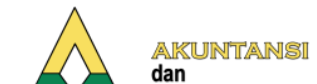

variabel tidak bebas adalah biaya dari suatu kegiatan. Adapun hasil yang diperoleh dari pengelolaan data ASB Pelatihan Bagi Aparatur dengan menggunakan program SPSS adalah sebagai berikut:

Tabel 1. Hasil Pengolahan Data Menggunakan SPSS Pada ASB Kegiatan Pelatihan Bagi Aparatur

\begin{tabular}{|c|c|c|c|c|c|c|}
\hline \multirow{2}{*}{\multicolumn{2}{|c|}{ Model }} & \multicolumn{2}{|c|}{ Unstandardized Coefficients } & \multirow{2}{*}{$\begin{array}{c}\begin{array}{c}\text { Standard } \\
\text { ized } \\
\text { Coefficie } \\
\text { nts }\end{array} \\
\text { Beta }\end{array}$} & \multirow{2}{*}{$\mathrm{t}$} & \multirow{2}{*}{ Sig. } \\
\hline & & B & Std. Error & & & \\
\hline & $\begin{array}{l}\text { (Cons } \\
\text { tant) }\end{array}$ & 7003161.654 & 2275662.133 & & 3.077 & 0.008 \\
\hline & $x$ & 124803.64 & 5863.288 & 0.985 & 21.286 & 0 \\
\hline
\end{tabular}

a. Dependent Variable: y

Sumber: Hasil olahan data di program SPSS

Tabel di atas menunjukan bahwa:

$\triangleright$ BelanjaTetap/Konstanta(a) $=7.003 .162$

$\triangle$ Belanja Variabel (b) $\quad=124.803$

$\triangle$ Signifikasi (Sig) $\quad=0,03077$

Pastikan signifikansi (Sig.) memiliki nilai diantara 0,000 sampai dengan 0,050. Nilai koefisien regresi layak digunakan apabila nilai signifikansi maksimum atau paling besar 0,050 atau 5\% [7]. Nilai Signifikansi pada ASB Pelatihan Bagi Aparatur adalah ,025 dan ,000. Karena nilai signifikansi pada kegiatan ini lebih kecil dari 0,05 atau 5\%, maka ini berarti signifikan dan sudah sesuai dengan persyaratan kelayakan koefisien yang memiliki tingkat keyakinan yang cukup tinggi serta siap digunakan.

Berdasarkan model diatas didapat persamaan/model ASB untuk menentukan total anggaran pada jenis ASB Pelatihan Bagi Aparatur ini sebagai berikut:

Total Belanja $=$ Rp. 7.003.162 +

124.804X

Keterangan: $X=$ Jumlah peserta pelatihan $\mathrm{x}$ Jumlah jam pelatihan

b. Menentukan presentase alokasi belanja rata-rata, batas bawah dan batas atas. Alokasi total belanja ASB Pelatihan Bagi Aparatur dapat dilakukan dengan cara sebagai berikut:

Berdasarkan persamaan 2.2, adapun penentuan persentase batasan alokasi belanja untuk total belanja jenis kegiatan ASB Pelatihan Bagi Aparatur jika standar deviasi sebesar 25\%. Perhitungannya sebagai berikut:

Tabel 2. Perhitungan Rata-rata Batas Bawah dan Batas Atas ASB Pelatihan Bagi Aparatur. 


\begin{tabular}{|r|l|c|c|c|}
\hline No & \multicolumn{1}{|c|}{ Keterangan } & Batas Bawah & Rata-Rata & Batas Atas \\
\hline 1 & Belanja Bahan Habis pakai & $11.13 \%$ & $14.84 \%$ & $18.55 \%$ \\
\hline 2 & Belanja Jasa kantor & $7.54 \%$ & $10.05 \%$ & $12.56 \%$ \\
\hline 3 & Belanja Cetak dan Pengadaan & $6.15 \%$ & $8.20 \%$ & $10.25 \%$ \\
\hline 4 & Belanja Makanan dan Minuman & $35.11 \%$ & $46.81 \%$ & $58.51 \%$ \\
\hline 5 & Belanja Perjalanan Dinas & $13.14 \%$ & $17.92 \%$ & $22.40 \%$ \\
\hline 6 & Belanja Jasa Pihak Ke Tiga & $1.63 \%$ & $2.18 \%$ & $2.72 \%$ \\
\hline \multicolumn{2}{|c|}{ Total } & & $100 \%$ \\
\hline & Sumber : Hasil Olahan Penulis & & \\
\end{tabular}

Berdasarkan perhitungan tersebut dapat diringkas batasan alokasi belanja ASB Pelatihan Bagi Aparatur adalah sebagai berikut:

Tabel 3. Batasan Alokasi Belanja ASB Pelatihan Bagi Aparatur

\begin{tabular}{|l|r|r|r|r|r|}
\hline \multicolumn{1}{|c|}{$\begin{array}{c}\text { Nama Alokasi } \\
\text { Belanja }\end{array}$} & $\begin{array}{c}\text { Total Alokasi } \\
\text { Belanja }\end{array}$ & Rata-Rata & \multicolumn{1}{c|}{$\%$} & \multicolumn{1}{c|}{ Batas Bawah } & Batas Atas \\
\hline \multicolumn{1}{|c|}{$(1)$} & $(3)=(2) /(7)$ & $(4)$ & $(5)=(3)+\{(4) *(3)\}$ & $(5)=(3)-\left\{(4)^{*}(3)\right\}$ \\
\hline $\begin{array}{l}\text { Belanja Bahan Habis } \\
\text { pakai }\end{array}$ & 118.123 .300 & $14.84 \%$ & $25 \%$ & $11.13 \%$ & $18.55 \%$ \\
\hline Belanja Jasa kantor & 80.000 .000 & $10.05 \%$ & $25 \%$ & $7.54 \%$ & $12.56 \%$ \\
\hline $\begin{array}{l}\text { Belanja Cetak dan } \\
\text { Pengadaan }\end{array}$ & 65.270 .000 & $8.20 \%$ & $25 \%$ & $6.15 \%$ & $10.25 \%$ \\
\hline $\begin{array}{l}\text { Belanja Makanan } \\
\text { dan Minuman }\end{array}$ & 372.608 .275 & $46.81 \%$ & $25 \%$ & $35.11 \%$ & $58.51 \%$ \\
\hline $\begin{array}{l}\text { Belanja Perjalanan } \\
\text { Dinas }\end{array}$ & 142.637 .957 & $17.92 \%$ & $25 \%$ & $13.44 \%$ & $22.40 \%$ \\
\hline $\begin{array}{l}\text { Belanja Jasa Pihak } \\
\text { Ke Tiga }\end{array}$ & 17.335 .000 & $2.18 \%$ & $25 \%$ & $1.63 \%$ & $2.72 \%$ \\
\hline Total Belanja (7) & 797.974 .532 & $100 \%$ & & & \\
\hline
\end{tabular}

ASB Pelatihan Bagi Aparatur ini hanya mengalokasikan objek belanja untuk belanja bahan habis pakai, belanja jasa kantor, belanja cetak dan penggandaan, belanja makanan dan minuman, belanja perjalanan dinas serta belanja jasa pihak ketiga. Suatu kegiatan Pelatihan Bagi Aparatur/pegawai yang pelaksanaannya yang akan 


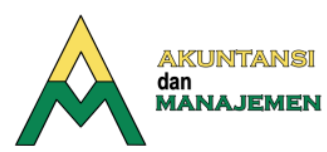

https://akuntansi.pnp.ac.id/jam

e-ISSN 2657-1080, p-ISSN 1858-3687

memasukkan objek belanja selain dari yang tersebut diatas maka dapat menambahkannya dalam perhitungan tambahan tersendiri dengan persetujuan tim evaluasi anggaran. ASB Pelatihan Bagi Aparatur ini akan efektif untuk output (jumlah peserta pelatihan x jumlah jam pelatihan) berkisar antara 130 sampai 840 .

Tabel batasan alokasi belanja diatas merupakan acuan untuk memudahkan alokasi belanja dalam jenis kegiatan Pelatihan Bagi Aparatur. Persentase yang didapatkan dari olahan data tersebut ditujukan jika akan dianggarkan suatu kegiatan Pelatihan Bagi Aparatur. Hal ini memudahkan tim penyusunan anggaran daerah kabupaten padang pariaman dalam mengalokasikan ataupun mengevaluasi kelayakan belanja untuk kegiatan Pelatihan Bagi Aparatur. Untuk informasi tambahan bahwa standar deviasi sebesar 25\% bisa berubah sesuai kesepakatan dengan OPD terkait.

\section{Contoh Melakukan Pengujian Kewajaran biaya dan beban kerja Kegiatan Pelatihan Bagi Aparatur}

Pada tahap ini adalah melakukan penilaian kewajaran atas biaya dan beban kerja yang digunakan dalam melaksanakan suatu kegiatan. Dalam penilaian kewajaran beban kerja aspek yang diperhatikan adalah kaitan logis antara kegiatan diusulkan dengan sasaran pembangunan, kesesuaian antara program dan kegiatan yang diusulkan dan kemampuan SKPD untuk melaksanakan program dan kegiatan dengan tingkat pencapaian yang diinginkan dalam jangka waktu 1 tahun anggaran. Sedangkan aspek yang diperhatikan dalam penilaian kewajaran biaya adalah kaitan antara biaya yang dianggarkan dengan target pencapaian kinerja, kaitan antara standar biaya dengan harga yang berlaku dan kaitan antara biaya yang dianggarkan dengan target pencapaian kinerja dengan sumber daya.

a. Penilaian kewajaran biaya

Kewajaran biaya adalah biaya per komponen atau biaya total yang wajar untuk menyelesaikan suatu kegiatan tertentu atau untuk menghasilkan satuan output tertentu. Dalam melakukan penilaian kewajaran biaya hal-hal yang harus dilakukan adalah menghitung rata-rata, batas bawah dan batas atas sesuatu kegiatan ASB yang disusun berdasarkan persamaan yang telah disusun. Kemudian membandingkan total belanja yang terdapat pada Dokumen Pelaksanaan Anggaran (DPA) atau Dokumen Perubahan Pelaksanaan Anggaran (DPPA) dengan total belanja ASB berdasarkan rata-rata, batas bawah dan batas atas.

Data yang didapatkan pada tahap pengumpulan data semuanya wajar karena tidak ada yang melebihi batas maksimum dan dibawah batas minimum total belanja menurut ASB. Total belanja kegiatan yang berada di atas batas atas setelah penyusunan ASB ditakutkan akan terjadi pemborosan anggaran, begitu juga dengan anggaran yang berada jauh pada batas bawah ditakutkan tujuan yang akan dicapai untuk pelaksanaan sebuah kegiatan tidak dapat tercapai secara maksimal. Sedangkan keterangan wajar pada kegiatan tersebut menunjukkan bahwa total belanja yang terdapat di DPA/DPPA berada pada rentang batas bawah dan batas atas total belanja menurut ASB. 


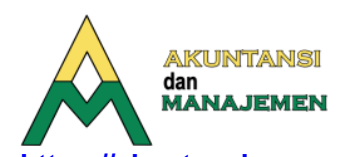

https://akuntansi.pnp.ac.id/jam

b. Penilaian kewajaran beban kerja

Beban kerja adalah komponen belanja yang mencerminkan tahapan pelaksanaan kegiatan, terdiri dari: belanja pegawai, belanja barang/jasa, dan belanja modal yang dapat menyelesaikan suatu kegiatan tertentu atau untuk menghasilkan satuan output tertentu. Langkah yang dilakukan dalam penilaian kewajaran beban kerja tidak jauh berbeda dengan melakukan penilaian kewajaran biaya. Perbedaannya adalah dalam menilai kewajaran beban kerja terfokus pada alokasi dari total belanja yang dianggarakan dalam dokumen pelaksanaan anggaran (DPA) atau dokumen perubahan pelaksanaan anggaran (DPPA). Adapun hasil dari penilaian kewajaran beban kerja untuk ASB Pelatihan Bagi Aparatur.

\section{Kesimpulan dan Saran}

\section{Kesimpulan}

ASB (Analisis Standar Belanja) merupakan penilaian kewajaran atas beban kerja dan biaya yang digunakan untuk melaksanakan suatu kegiatan. Atas dasar pengertian tersebut, maka ASB dapat dipandang sebagai total biaya kegiatan/keluaran, yaitu jumlah biaya untuk menghasilkan kegiatan yang dapat diukur atas dasar output kegiatan ataupun per kegiatan itu sendiri.

Dalam penyusunan ada terdapat beban kerja dan beban biaya. Beban kerja adalah komponen belanja yang mencerminkan tahapan pelaksanaan kegiatan, terdiri dari: belanja pegawai, belanja barang/jasa dan belanja modal yang dapat menyelesaikan suatu kegiatan tertentu untuk menghasilkan satuan output tertentu. Biaya wajar adalah biaya per komponen biaya atau biaya total yang wajar untuk dapat menyelesaikan suatu kegiatan tertentu atau untuk menghasilkan satuan output tertentu.

Dalam penyusunan ASB ini termasuk pada tahap pengumpulan data, tahap inventarisasi data, menentukan cost driver, melakukan pengujian menggunakan Diagram Pencar/Scatter Plot, penyusunan model analisis Standar belanja (ASB), terdiri dari: membuat persamaan regresi untuk setiap kegiatan Analisis Standar Belanja (ASB) menggunakan program SPSS menentukan persentase alokasi belanja rata-rata, batas atas,dan batas bawah. Kemudian dilakukan Penilaian ASB setelah penyusunan model.

ASB ini tidak memiliki jangka waktu pemakaiannya. ASB dapat digunakan selama di dalam pemerintahan tersebut tidak terjadi perubahan biaya suatu kegiatan secara signifikan. Jika hal itu terjadi maka perlu dilakukan pembaharuan ASB tersebut. Pemerintah Kabupaten Padang Pariaman sebelumnya belum memiliki ASB sebagia standar dalam menentukan anggaran kegiatan yang dilaksanakan pada setiap OPD. ASB yang disusun ini hanya dapat digunakan di Pemerintah Kabupaten Padang Pariaman saja.

\section{Saran}

Penelitian ini dilakukan pada Pemerintah Daerah Kabupaten Padang Pariaman saja, penelitian ini bisa di lakukan di Kota lainnya yang belum memiliki acuan khusus yang 


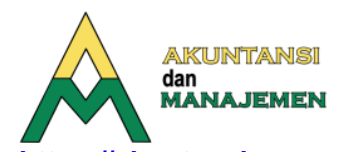

https://akuntansi.pnp.ac.id/jam

e-ISSN 2657-1080, p-ISSN 1858-3687

diterapkan secara optimal dalam penganggaran kegiatan-kegiatan yang sering dilaksanakan dan spesifik oleh OPD

\section{Ucapan Terima Kasih}

Terima kasih kami ucapkan kepada Pemda Kabupaten Padang Pariaman dan politeknik negeri Padang yang telah mendukung moril dan data yang telah diberikan

\section{Referensi}

[1] Bastian. Indra. 2006. Sistem Perencanaan dan Penganggaran Pemerintah Daerah di Indonesia. Jakarta: Salemba Empat.

[2] Bambang, Sancoko dkk. 2008. Kajian Terhadap Penerapan Penganggaran Berbasis Kinerja di Indonesia. Departemen Keuangan Republik Indonesia.

[3] Blocher, dkk. 2011. Manajemen Biaya. Jakarta: Salemba Empat.

[4] Budiardjo, Miriam. 2003. Dasar-Dasar Ilmu Politik. Jakarta: Gramedia Pustaka Utama.

[5] Gunawan, Imam. 2017. Pengantar Statistika Inferensial. Edisi Pertama. Jakarta: Rajawali Pers.

[6] Halim, Abdul. 2007. Akuntansi Keuangan Daerah. Jakarta : Salemba Empat.

[7] Heryanto, Imam dan Totok Triwibowo. 2018. Path Analysis Menggunakan SPSS dan Excel. Bandung : Informatika Bandung.

[8] Karianga, Hendra. 2017. Carut Marut Pengelolaan Keuangan Daerah Di Era Otonomi Daerah. Jakarta: Kencana.

[9] Putra, Windhu. 2018. Tata Kelola Keuangan Daerah. Depok : Rajawali Pers.

[11]Pusat Studi Keuangan Daerah (PSKD). 2010. Modul Analisis Standar Belanja : Konsep dan Implementasi. Padang: Fakultas Ekonomi Universitas Andalas.

[12]Republik Indonesia. 2011. Permendagri Nomor 21 Tahun 2011 Tentang Perubahan Kedua Atas Peraturan Menteri Dalam Negeri Nomor 13 Tahun 2006 Tentang Pedoman Pengelolaan Keuangan Daerah. Menteri Dalam Negeri. Jakarta.

[13]Tim ASB Universitas Andalas. 2015. Analisa Standar Belanja. Padang. 